\title{
Body mass index at calving on performance and efficiency of Zebu cow herds
}

\section{Î́ndice de massa corporal ao parto no desempenho e eficiência de rebanhos de vacas Zebuínas}

\author{
Ricardo Zambarda Vaz ${ }^{1 *}$; Liliane Cerdótes ${ }^{2}$; Rangel Fernandes Pacheco3; \\ Dayana Bernardi Sarzi Sartori; Jeniffer Danielle Lucas ${ }^{5}$; Hilda Solange Souza \\ Agner ${ }^{5}$; João Restle ${ }^{6}$
}

\section{Highlights}

Non-ideal nutritional conditions limit reproductive performance.

Lower body mass index determines higher yields.

Cows with higher body mass indices produce heavier calves.

\begin{abstract}
This study examines the impact of the body mass index (BMI) at calving on the development and postpartum efficiency of cows of Zebu origin. The study involved 87 cows and their calves [pure Nellore $(\mathrm{N})$ or predominant Nellore composition in a cross with Charolais (C) (3/4N1/4C and 5/8N3/8C)]. The mothers were grouped into classes according to their BMI at calving, namely, 'small', 'moderate' and 'large'. Body mass index was determined by dividing the body weight of the cows by their length and by hip height and then dividing the result by 10 . Cows were weighed at calving, at weaning, at the end of the breeding period and at the diagnosis of pregnancy. Calves were weighed at birth, at early weaning (63 days) and at 210 of age. To evaluate milk yield and quality, milk was collected at 21, 42 and 63 days after calving. Milk yield was measured by the direct method, with manual milking, followed by analysis of the lactose, fat, total solids and crude protein contents. Pregnancy rate was similar between the three BMI groups; however, cows with a lower BMI were more efficient at calving in producing kilograms of calf per kilogram of cow kept. Higher BMI provide higher milk yields, without affecting its quality, as well as heavier calves at early weaning and at 210 days of age.
\end{abstract}

Key words: End of the breeding period. Milk production and quality. Pregnancy. Weaning.

1 Associate Prof. Dr., Department of Animal Science, Universidade Federal de Santa Maria, UFSM, Palmeira das Missões, RS, Brazil. E-mail: rzvaz@terra.com.br

2 Profa Dra, Instituto Federal Catarinense, IFC, Santa Rosa do Sul, SC, Brazil. E-mail: liliane.cerdotes@ifc.edu.br

3 Prof. Dr., Instituto Federal Farroupilha, IFFar, Frederico Westphalen, RS, Brazil. E-mail: rangel.pacheco@ iffarroupilha,edu,br

${ }^{4}$ Master Student of the Postgraduate Course in Agribusiness, UFSM, Palmeira das Missões, RS, Brazil. E-mail: dayanabernardisartori@gmail.com

5 Graduate, UFSM, Palmeira das Missões, RS, Brazil. E-mail: jhen.lucas@outlook.com; hilda.agner@hotmail.com

${ }^{6}$ Prof. Dr., Postgraduate Program Animal Science, Universidade Federal de Goiás, UFG, Goiânia, GO, Brazil. E-mail: jorestle@terra.com.br

* Author for correspondence

Received: June 21, 2021 - Approved: Oct. 15, 2021 


\section{Resumo}

O objetivo dessa pesquisa foiavaliar o impacto do índice de massa corporal(IMC) ao parto no desenvolvimento e eficiência pós-parto de vacas de origem zebuína. Utilizou-se 87 vacas e seus bezerros [Nelore (N) puros ou com predominância em cruzamento com Charolês (C) (3/4N1/4C e 5/8N3/8C)], agrupadas em classes segundo o seu IMC ao parto, em 'pequenas', 'moderadas' e 'grandes'. O índice de massa corporal foi determinado através da divisão do peso corporal das vacas pelo seu comprimento e pela altura de quadril e posteriormente o resultado dividido por 10. As vacas foram pesadas no parto; ao desmame; final da monta e no diagnóstico de gestação. Os bezerros foram pesados ao nascimento, na desmama precoce (63 dias) e aos 210 dias de idade. Para a avaliação da produção e qualidade do leite das vacas foram realizadas três coletas aos 21, 42 e 63 dias após o parto. A medida da produção de leite foi realizada pelo método direto, com ordenha manual, seguida de análise do teor de lactose, gordura, extrato seco total e proteína bruta. A taxa de prenhez foi similar para os três índices de massa corporal, no entanto vacas de menor IMC foram mais eficientes ao parto na produção de quilogramas de bezerros por quilograma de vaca mantida. O IMC alto propicia maior produção de leite sem que a qualidade seja alterada e bezerros mais pesados no desmame precoce e no peso aos 210 dias.

Palavras-chave: Desmame. Final da monta. Prenhez. Produção e qualidade do leite.

\section{Introduction}

The growing demand for beef has driven producers to aim at increased productivity rates, since the prices paid for the meat product are breaking records, according to the United States Department of Agriculture [USDA] (2020). Increasing herd productivity rates entails choosing animals that better adapt to production systems and are thus more efficient and productive (Burrow, 2010; Carvalheiro et al., 2019; Leal et al., 2018).

Production systems do not normally prioritize beef dams. Therefore, these animals are subjected to pastures with low nutritional levels, resulting in low pregnancy rates, low weights at weaning, prolonged calving intervals and, ultimately, low profitability (Freetly, Kuehn, \& Cundiff, 2011; Gano, Blanco, Casasús, Cortés-Lacruz, \& Villalba, 2016). Nutritional restrictions during pregnancy and lactation can affect the growth and development of muscle fibers and marbling cells, which are formed in the prenatal period, compromising animal development and meat quality (Du et al., 2010; Gutiérrez et al., 2014). In addition, the likelihood of pregnancy recurrence may be reduced (Pacheco et al., 2020a).

Factors such as the body structure (Scasta, Henderson, \& Smitht, 2015), weight at calving (Chud et al., 2014; Michael, Baruselli, \& Campanile, 2019; Vaz et al., 2020a) and body condition score (Michael et al., 2019) of beef cows can be used as indicators of the development and productivity of a breeding herd. However, although the weight at calving appears to be a good performance indicator for breeding herds, it may have controversial effects on the cow's reproductive performance (Chud et al., 2014) and on the efficiency of the herd (Marques, Cooke, Rodriguez, Moriel, \& Bohnert, 2016) if evaluated in isolation.

Thus, body weight alone does not adequately represent the condition of a cow, since two cows can have identical weights, but 
different sizes, as well as different muscle and fat mass accumulation. In an effort to correct these effects, the body mass index (BMI) was proposed to adjust the weight of the animal to its height. Additionally, the length of the animal can also be used, further enhancing the index.

Body mass index thus emerges as an indicator of body condition, as it provides a better understanding of the animal's body development. In beef cows, high BMI values are thought to correlate with high body weights (Gabriel et al., 2016). The body condition of cows is directly related to their milk yield (Lemes, Pimentel, Vaz, Farias, \& Brauner, 2017; Marques et al., 2016) and, consequently, to the development of their calves (Vaz et al., 2020b).

Therefore, the present study proposes to examine the impact of the BMI of Nellore cows and cows with predominant Nellore genetic composition on their postpartum development, efficiency, milk yield and calf development.

\section{Material and Methods}

\section{Study location}

The study was conducted in the municipality of Santa Maria, located in the Central Depression region, RS, Brazil (29\%43' $\mathrm{S}$ and $53^{\circ} 42^{\prime} \mathrm{W} ; 95 \mathrm{~m}$ asl). The climate of the region is a humid subtropical type.

\section{Animals, treatment, diets and management}

A total of 87 cows and their calves [Nellore breed ( $\mathrm{N}-32$ cows) or with predominant Nellore composition in crosses with the Charolais breed (C) (3/4N1/4C - 28 cows and 5/8N3/8C - 27 cows)] were used. Cows aged between tree and nine years were distributed into classes according to their BMI at calving, namely, 'small', 'moderate' and 'large'.

The BMI classes were determined according to their overall mean and standard deviation of the mean. The groups were formed from the addition or subtraction of 0.5 standard deviations (1.08 points) from the overall mean BMI of the cows, which was 19.59 points. The groups were thus defined as follows: 'small' (cows with a mean BMI of 17.28 points, ranging from 15.04 to 18.45 points); 'moderate' (mean BMI of 19.41 points, ranging from 18.52 to 20.67 points); and 'large' (mean BMI of 22.09 points, ranging from 20.71 to 24.98 points). Each treatment had a total of 29 cows.

Body mass index was calculated by dividing the cow's body weight at calving (CBW) by its hip height $(\mathrm{HH})$ and by its length (L) and subsequently dividing the result by 10 (Costa et al., 2020), according to the following formula:

$$
\mathrm{BMI}=(\mathrm{CBW} / \mathrm{HH} / \mathrm{L}) / 10
$$

Cow length was measured using a tape measure, between the scapulohumeral and coxofemoral joints. Hip height was determined using a set square, which measured the distance between the upper part of the sacrum and the soil surface.

Regardless of the cow or calf group, all were kept under the same management conditions during the experimental period, with births occurring in the spring, over an 86day period. To conceive these calves, the cows were subjected to a reproductive management consisting of 45 days of artificial insemination and 45 days of natural breeding, starting 43 days after the average calving date. 
From birth to early weaning ( $63 \pm 3$ days of age), calves and dams remained in natural pasture areas with a carrying capacity of 0.9 $\mathrm{AU} \mathrm{ha}^{-1}(\mathrm{AU}=$ animal unit, equivalent to $450 \mathrm{~kg}$ of body weight [BW]), where they received daily energy supplementation with brown rice bran at the rate of $0.7 \%$ of the cow's body weight. After weaning, all calves were kept in a pen for five days, where they received commercial feed with $22 \%$ crude protein. Subsequently, for a period of 30 days, the diet was based on maize silage and concentrate feed (at 1\% BW) containing $18 \%$ crude protein. After this period, the calves were transferred to the millet (Penisetum americanum Leeke) pasture area, using the same concentrate and the same proportion. From five to 12 months of age, the animals remained in natural pasture areas and were supplemented with maize silage and concentrate (1\% BW).

\section{Measurements and calculations of indicators}

The cows and calves were weighed at birth, at weaning, at 150 days and at 210 of age. The animals were also weighed every 21 days to control and adjust the stocking density. Weight gains were calculated as the difference between the weighing events divided by the number of days in the interval. The production efficiency of the cows at calving and at weaning was calculated by dividing the weight of the calves at weaning by the body weight of cows at calving and weaning, respectively, and multiplying the result by 100 . Results were expressed in kilograms of calf per 100 kilograms of cow in the herd (Silveira et al., 2019). The calf production index was determined by multiplying the pregnancy rate of the cows by the weight of the calves at weaning, and expressed in kilograms of calf weaned per cow in the herd (Silveira et al., 2019).

\section{Evaluation of milk production and quality}

To evaluate milk yield and quality, milk was collected at 21, 42 and 63 days after calving. Milk yield was determined by the direct method, with manual milking. To this end, the cows were separated from their calves in the morning (one day before collection) and kept in an annex paddock. At 18h00, the cows were placed again with the calves, where they remained for $30 \mathrm{~min}$, aiming at the udder depletion. Afterwards, the calves were separated again from their mothers and kept in the pen until the following morning. The cows started to be milked approximately $12 \mathrm{h00}$ after the last suckle. For this, they were restrained by the neck and intramuscularly injected with $30 \mathrm{IU}$ (international units) of oxytocin, to facilitate milk letdown. Milking was performed in two udder quarters, one front and one rear. The obtained production was multiplied by two, to calculate the total udder production, and later adjusted to $24 \mathrm{h00}$ (Restle et al., 2005). Total milk yield was estimated as the sum of measurements from days 21,42 , and 63 postpartum multiplied individually by 21. A $450 \mathrm{~mL}$ sample of the extracted milk was taken and immediately cooled for analysis (Laboratory of the Dairy Herd Analysis Service - SARLE, at the Food Research Center of the University of Passo Fundo - UPF) of the lactose, fat, total solids and crude protein contents. 


\section{Statistical analysis}

The obtained data were subjected to analysis of variance at the $5 \%$ level. Means were compared by the t-test, using the SAS 9.0 statistical program, in which the following mathematical model was applied:

$$
\begin{gathered}
Y i j k l=\mu+B M l i+A C j+\left(A C^{*} A C j\right)+B O k+G G I \\
+\varepsilon i j k l,
\end{gathered}
$$

where Yijk $=$ dependent variables (body measurements); $\mu$ = average of all observations for a given trait; BMli = effect of body mass index i (1 = small; 2 = moderate; and 3 = large); $A C j=$ linear effect of the covariate 'age of cow with index $j^{\prime} ;\left(A C^{*} A C j\right)=$ quadratic effect of the covariate 'age of cow with index j'; BOk = covariate 'calf birth order k'; GGI = covariate 'genetic group with index I' and $\varepsilon i j \mathrm{kl}=$ random residual effect.

\section{Results and Discussion}

The cows classified as 'large' based on their BMI were heavier than the 'moderate' cows at calving, at weaning, at the end of the breeding period and at the diagnosis of pregnancy. The latter, in turn, were heavier than the cows classified as 'small'. This finding reinforces the fact that $\mathrm{BMI}$ is well-distributed between the classes (Table 1).

\section{Table 1}

Means and standard errors of development and milk-yield traits of Nellore and Nellore crossbred cows

\begin{tabular}{|c|c|c|c|}
\hline \multirow[b]{2}{*}{ Trait } & \multicolumn{3}{|c|}{ Body mass index class } \\
\hline & Small & Moderate & Large \\
\hline \multicolumn{4}{|l|}{ Weight, kg } \\
\hline Cow, at calving & $334.9 \pm 6.5 c$ & $372.0 \pm 5.8 b$ & $423.2 \pm 6.4 a$ \\
\hline Cow, at weaning & $336.5 \pm 7.2 \mathrm{c}$ & $378.6 \pm 6.5 b$ & $422.3 \pm 7.1 a$ \\
\hline End of breeding season & $355.9 \pm 7.2 \mathrm{c}$ & $398.7 \pm 6.5 b$ & $443.4 \pm 7.8 a$ \\
\hline Pregnancy diagnosis & $390.6 \pm 8.6 c$ & $433.1 \pm 7.7 b$ & $481.1 \pm 8.4 a$ \\
\hline Calf, at birth & $29.9 \pm 1.1 a$ & $30.8 \pm 0.9 a$ & $31.7 \pm 1.0 a$ \\
\hline Calf, at weaning (63 days) & $62.6 \pm 2.2 b$ & $69.2 \pm 2.0 a$ & $73.2 \pm 2.1 a$ \\
\hline Calf, at 150 days & $94.6 \pm 3.4 b$ & $101.6 \pm 3.1 b$ & $112.2 \pm 3.4 a$ \\
\hline Calf, at 210 days & $125.2 \pm 4.5 b$ & $133.8 \pm 4.1 a$ & $141.8 \pm 4.4 a$ \\
\hline \multicolumn{4}{|l|}{ Daily weight change, $\mathrm{kg}$} \\
\hline Cow, in lactation & $0.021 \pm 0.051 a$ & $0.101 \pm 0.045 a$ & $-0.014 \pm 0.050 b$ \\
\hline Calf, in milk feeding & $0.541 \pm 0.031 b$ & $0.608 \pm 0.028 a b$ & $0.641 \pm 0.030 a$ \\
\hline \multicolumn{4}{|l|}{ Milk yield, $L$} \\
\hline Total & $212.7 \pm 19.3 b$ & $253.1 \pm 18.9 a$ & $265.1 \pm 20.7 a$ \\
\hline Average daily & $3.37 \pm 0.3 b$ & $4.01 \pm 0.3 a$ & $4.21 \pm 0.4 a$ \\
\hline
\end{tabular}
with different body mass indices

$a, b, c$ in the same row differ $(P<0.05)$ between BMI. 
In beef cows, higher body weights at calving and at the end of the breeding period translate into higher pregnancy rates (Farias et al., 2018a). This is because these variables indicate the nutritional status of the females during pregnancy and lactation.

Cows that gain weight between mating and calving are more likely to repeat pregnancy, especially during the growing phase (Pacheco et al., 2020a). However, in pasture-based production systems, fluctuations in the quantity and quality of forage can compromise the nutritional status of dams at some times of the year (Gutiérrez et al., 2014). When postpartum nutrition is compromised, heavier cows may have their reproductive performance impaired (Vaz et al., 2020a). On the other hand, when the nutritional level is adequate, body weight at calving does not influence the reproductive performance of adult beef cows (Moura et al., 2014; Vara et al., 2020). Beef cows must have adequate body reserves to ensure basic reproductive vital functions and milk production postpartum (Lemes et al., 2017; Marques et al., 2016).

Calf birth weight did not differ between the cow BMI classes. At weaning (63 days), the calves born to large and moderate cows (73.2 $\mathrm{kg}$ and $69.2 \mathrm{~kg}$, respectively) were heavier and achieved higher daily body weight gains in the period than those born to small cows $(62.6 \mathrm{~kg})$.

The large and moderate cows had higher milk yields than the small cows until weaning, when their calves were 63 days old, which resulted in the calves from the first two groups having a higher body weight. These results support the hypothesis that the cow's milk determines its progeny performance (Dervishi et al., 2017; Rodrigues et al., 2014). Up until weaning, besides the genetic factor, calves are highly dependent on the maternal environment, which is almost exclusively determined by the milk yield of their mothers. Vara et al. (2020) worked with the same weaning age, but body size classes at calving, and found that calves from large cows were heavier at birth and at weaning than those born to small cows.

At 210 days of age, the calves born to large and moderate cows were heavier than those born to small cows. Because weaning took place at 63 days, calf weight at 210 days should not be influenced by their milkfeeding period, since animal development in the post-weaning period varies with its growth potential and interactions with environmental conditions (Moura et al., 2014; Silveira et al., 2019). However, daily weight changes in the post-weaning period were similar between the three BMl groups. This demonstrates the importance of milk production for calf development, since even in a short suckling period, the difference established by the higher milk yield of the large and moderate cows persisted until the calves were 210 days old. This was true even in the post-weaning period, as the calves from the three BMI groups showed similar development.

Changes in average daily weight during lactation were negative and lower in the large cows than in those classified as moderate and small, which indeed had weight gains. The lower weight gain of the large cows can be explained by the higher nutritional requirement of larger and heavier animals for maintenance National Research Council [NRC] (2016). Another explanation for the lower weight gain in cows with higher BMI is that they have already expressed their maximum growth potential for the environmental conditions to which they were subjected, thereby allocating more energy to milk production at the expense 
of weight gain. In the present study, in addition to their larger size, the cows classified as large produced more milk, which is the most stressful process for a dam during its production cycle (Lemes et al., 2017). The literature is contradictory as to the body weight change of cows during lactation, with average daily gain depending on nutrition during the period. In an experiment in which cows were provided with sufficient amounts of dry matter in Brachiaria brizantha pastures, no difference was found in daily weight change during lactation, until 67 days postpartum, in higher-yielding cows, despite their greater wear in comparison to the lower-yielding cows (Vaz et al., 2020b).

Daily and total milk yields differed between the BMI classes, with the small cows having lower daily and total values than the moderate and large cows. Smaller cows produce less milk due to their smaller size and lower synthesis efficiency (Fonseca et al., 2012), which results in lighter calves at weaning (Dervishi et al., 2017; Vara et al., 2020). However, pre- and postpartum nutrition (Lemes et al., 2017; Marques et al., 2016) and the calving season (Bitencourt et al., 2020) can influence the amount of milk produced. There was no difference in pregnancy rate between the BMl classes (Table 2).

M. D. Silva, Lobato, Vaz, Eloy and Vaz (2018) evaluated different ratios of weight $(\mathrm{kg})$ to hip height $(\mathrm{cm})$ in Hereford heifers mated at 14-15 months of age and also found no differences in pregnancy rate. However, in the present experiment, all groups had reached the minimum weight recommended for their mating age.

Pregnancy in beef cows is influenced by several factors (Pacheco et al., 2020a). A larger body size can have negative effects on reproductive performance, as compared with smaller sizes, when the postpartum feeding system is not ideal (R. M. Silva et al., 2015) or when the cows are primiparous and have their first lactation while still growing (Pacheco et al., 2019b; Vaz et al., 2020a). In this regard, the primiparous condition is a determining factor even in good nutritional conditions (Castilho et al., 2018). On the contrary, with the use of postpartum supplementation (Farias et al., $2018 a, b)$ or calcium salt supplementation in the pre- and postpartum periods in adult cows (Vara et al., 2020), pregnancy rates are influenced by cow body size.

\section{Table 2}

Means and standard errors for production and efficiency traits of herds of Nellore and Nellore crossbred cows with different body mass indices

\begin{tabular}{|c|c|c|c|}
\hline \multirow[b]{2}{*}{ Trait } & \multicolumn{3}{|c|}{ Body mass index class } \\
\hline & Small & Moderate & Large \\
\hline Pregnancy, \% & 60.6 & 69.0 & 66.9 \\
\hline Cow efficiency at calving ${ }^{1}, \mathrm{~kg}$ & $18.9 \pm 0.6^{a}$ & $18.6 \pm 0.6^{a}$ & $17.4 \pm 0.6^{a}$ \\
\hline Cow efficiency at weaning ${ }^{2}, \mathrm{~kg}$ & $18.8 \pm 0.6^{a}$ & $18.3 \pm 0.6^{a}$ & $17.5 \pm 0.6^{a}$ \\
\hline Cow efficiency at weaning ${ }^{3}, \mathrm{~kg}$ & $3.58 \pm 0.1^{a}$ & $3.57 \pm 0.1^{\mathrm{a}}$ & $3.33 \pm 0.1^{\mathrm{a}}$ \\
\hline Calf, at weaning (63 days) & $62.6 \pm 2.2^{b}$ & $69.2 \pm 2.0^{\mathrm{a}}$ & $73.2 \pm 2.1^{a}$ \\
\hline
\end{tabular}


The probability of pregnancy is directly related to the nutritional status of the cow as well as to its current energy balance, and its prolongation is harmful to the subsequent reproductive performance (Pacheco et al., 2020a; Torres, Tineo, \& Raidan, 2015). In the present study, the supplementation provided in the postpartum period may have influenced the results, as the cows were not subjected to a drastic negative energy balance, which led to satisfactory reproductive performances regardless of $\mathrm{BMI}$ class. Despite still being in lactation at the beginning of the reproductive period, the cows were weaned 21 days later. In another study, beef dams with satisfactory body condition at calving showed better pregnancy repetition rates, with their metabolic condition as well as body reserves determining reproductive performance in the subsequent breeding season (Bohnert et al., 2013).

The calf production index is directly related to pregnancy rate and to the weight of calves at weaning. It is an important indicator in the evaluation of breeding cow herds, as it reflects the potential for the production of kilograms of calf per cow exposed to reproduction. In this study, the higher calf production indices obtained by the large and moderate cows were in part because they weaned heavier calves than the cows classified as small. This indicator can, however, be influenced by age at weaning (Vaz, Lobato, \& Restle, 2010); the nutritional level of the cow pre- and postpartum with the use of cultivated pastures (Lemes et al., 2017); and supplementation with calcium salts (Silveira et al., 2019).

In a beef herd, production efficiency can be defined as the cows' ability to transform the ingested feed into calf weight at weaning. It also depends on their body weight at the different stages of the production cycle (Farias et al., 2018a,b). In the current study, when efficiency was evaluated as calf weight at weaning (63 days) associated with cow weight at calving and at weaning, the cows classified as small were more efficient than the 'large' class, but did not differ from those classified as moderate. Changes in cow body weight during lactation may not compensate for the increase in calf weight until weaning, when it is a result of increased milk production. As a consequence, cows lose efficiency in terms of $\mathrm{kg}$ of weaned calf/kg of cow, and this fact is accentuated with increasing age (Lemes et al., 2017). The production of kilograms of calf as a function of cow body weight is important because it indicates the cow's maternal ability. Additionally, it can be an excellent evaluation criterion, as it associates the energy expenditure for maintenance and production, whose response is the kilograms of calf produced. The higher efficiency of the 'small' cows in this study shows that although they produced lighter calves, their calf production in kilograms is more economical due to a probable lower feed intake resulting from their lower maintenance and production requirements (Vara et al., 2020), or even lesser use of areas for the maintenance of the calfcow pair (Farias et al., 2018a,b).

The literature does not comprise studies on the calf production index associating calf weaning weight with cow pregnancy as a function of the cow's BMI. However, when calf production index was evaluated in kilograms of calf per cow kept in the herd as a function of cow size or body weight class at calving, results were similar (Farias et al., 2018b) or favorable for larger or heavier cows when they were fully mature or 
received complementary postpartum feeding (Farias et al., 2018a; Vara et al., 2020). On the other hand, when cows were calving for the first time or were still growing in which case their pregnancy rate is usually compromised, the results of kilograms of calf per cow kept in the herd were higher in the cows with a smaller body size at calving (Castilho et al., 2018; Vaz et al., 2020a).

Calf performance was positively correlated with milk intake. However, not only the quantity of milk is important, but also its quality (Lemaster, Taylor, Ricks, \& Long, 2017). The qualitative traits of the milk from the cows evaluated in the present study did not differ between the BMI classes (Table 3).

The composition of milk from beef cows can be influenced by several factors, e.g. their breed (Rodrigues et al., 2014), age (Castilho et al., 2018) and, mainly, nutritional level and its interaction with their body reserves (Moura et al., 2014), which makes it difficult to discuss these results.

\section{Table 3}

Means and standard errors of quality parameters of milk from Nellore and Nellore crossbred cows with different body mass indices

\begin{tabular}{|cccc|} 
& \multicolumn{3}{c|}{ Body mass index class } \\
\cline { 2 - 4 } Qualitative component (\%) & Small & Moderate & Large \\
Mean values in lactation, \% & & $3.22 \pm 0.15^{\mathrm{a}}$ & $3.12 \pm 0.15^{\mathrm{a}}$ \\
\hline Protein & $3.23 \pm 0.15^{\mathrm{a}}$ & $3.65 \pm 0.17^{\mathrm{a}}$ & $3.65 \pm 0.17^{\mathrm{a}}$ \\
\hline Fat & $3.15 \pm 0.24^{\mathrm{a}}$ & $4.95 \pm 0.07^{\mathrm{a}}$ & $5.04 \pm 0.08^{\mathrm{a}}$ \\
\hline Lactose & $4.85 \pm 0.07^{\mathrm{a}}$ & $12.3 \pm 0.24^{\mathrm{a}}$ & $12.2 \pm 0.30^{\mathrm{a}}$ \\
Total solids & $12.1 \pm 0.28^{\mathrm{a}}$ & $8.71 \pm 0.14^{\mathrm{a}}$ & $8.70 \pm 0.17^{\mathrm{a}}$ \\
Solids-not-fat & $8.54 \pm 0.16^{\mathrm{a}}$ & &
\end{tabular}

$\mathrm{a}, \mathrm{b}, \mathrm{c}$ in the same row differ $(\mathrm{P}<0.05)$ between BMI.

Fonseca etal. (2012) also experimented with Nellore cows and described mean values close yet numerically higher than those found in the present study $(3.71 \%$ protein, $3.88 \%$ fat, $4.74 \%$ lactose and $13.43 \%$ total solids). Nonetheless, these authors worked with a 180-day lactation period, which may have caused the qualitative components of milk to concentrate, whereas in this study we only evaluated the peak milk production period. Vara et al. (2020) evaluated Charolais and Nellore cows and their crosses, grouped in different classes of body weight at calving, and found values similar to those of the present study. However, the small cows produced milk with the highest fat content, which was likely due to the presence of animals with a predominant Charolais composition, which are more nutritionally demanding. Likewise, in the study of Lemes et al. (2017), the moderateand large-sized cows were unable to obtain the nutrients necessary to produce fat in similar quantity to the light cows from natural pasture. 


\section{Conclusions}

Higher body mass indices at calving provide heavier cows in the postpartum period; higher milk yields; and heavier calves at weaning (at 63 days postpartum) and at 150 and 210 days of life, without compromising the cows' pregnancy rate. Cows classified as small based on their body mass index are more efficient in producing kilograms of calf at weaning per kilogram of cow at calving and at weaning. Body mass index does not influence the quality of milk produced by Nellore or Nellore crossbred cows. Despite being a technique that has an impact on production systems, early weaning is not a common practice in beef farms, and similar studies should be carried out in systems with the socalled "traditional" weaning with older calves.

\section{Compliance with ethical standards conflict of interest}

The authors declare that they have no conflict of interest.

\section{Statement on animal rights}

All procedures were approved by the Institutional Committee on Animal Use (CEEA no. 8250-2015).

\section{Acknowledgments}

Supported by Conselho Nacional de Desenvolvimento Científico e Tecnológico (CNPq), grant no. 303246/2015-4.

\section{References}

Bitencourt, M. F., Cerdótes, L., Restle, J., Costa, P. T., Fernandes, T. A., Ferreira, O. G. L., \& Vaz, R. Z. (2020). Age and calving time affects production efficiency of beef cows and their calves. Anais da Academia Brasileira de Ciências, 92(Suppl. 1), e20181058. doi: 10.1590/0001-3765202020181058

Bohnert, D. W., Stalker, L. A., Mills, R. R., Nyman, A., Falck, S. J., \& Cooke, R. F. (2013). Late gestation supplementation of beef cows differing in body condition score: effects on cow and calf performance. Journal of Animal Science, 91(11), 5485-5491. doi: 10.2527/jas.2013-6301

Burrow, H. (2010). Relative importance of adaptation and genotype $\mathrm{x}$ environment interactions in tropical beef breeding systems. Advances in Animal Biosciences, 1(2), 271-372. doi: 10.1017/ S2040470010000014

Carvalheiro, R., Costilla, R., Neves, H. H. R., Albuquerque, L. G., Moore, S., \& Hayes, B. J. (2019). Unraveling genetic sensitivity of beef cattle to environmental variation under tropical conditions. Genetics Selection Evolution, 51(1), 1-14. doi: 10. 1186/s12711-019-0470-x

Castilho, E. M., Vaz, R. Z., Fernandes, T. A., Farias, G. D., Boligon, A. A., Conceição, V. G. D., \& Brum, O. B. (2018). Precocidade de parto na estação de parição sobre a eficiência produtiva de vacas primíparas aos 24 meses de idade. Ciência Animal Brasileira, 19(9), 1-9. doi: 10.1590/1809$6891 v 19 e-46667$

Chud, T. C. S., Chud, T. C., Caetano, S. L., Buzanskas, M. E., Grossi, D. A., Guidolin, D. G., \& Munari, D. P. (2014). Genetic analysis for gestation length, birth weight, weaning weight, and accumulated productivity 
in Nellore beef cattle. Livestock Science, 170(1), 16-21. doi: 10.1016/j. livsci.2014.09.024

Costa, P. T., Mendonça, G., Brum, L. P., Vieira, T. P., Feijó, F. D., \& Vaz, R. Z. (2020). Body mass index, energy reserves, and tissue composition of cuts of Corriedale lambs. Pesquisa Agropecuária Brasileira, 55(1), e01908. doi: 10.1590/S1678-3921.pab 2020.v55.01908

Dervishi, E., Zhang, G., Dunn, S. M., Mandal, R., Wishart, D. S., \& Ametaj, B. N. (2017). GCMS metabolomics identifies metabolite alterations that precede subclinical mastitis in the blood of transition dairy cows. Journal of Proteome Research, 16(2), 433-446. doi: 10.1021/acs.jprote ome.6b00538

Du, M., Tong, J., Zhao, J., Underwood, K. R., Zhu, M., Ford, S. P., \& Nathaniel, P. W. (2010). Fetal programming of skeletal muscle development in ruminant animals. Journal Animal Science, 88(13), E51-E60. doi: 10.2527/jas.2009-2311

Farias, G. D., Cerdótes, L., Restle, J., Pascoal, L. L., Costa, P. T., Ferreira, O. G. L., \& Vaz, R. Z. (2018a). Body size and its effects on productive efficiency of cows with predominant Nellore genetic composition. Acta Scientiarium Animal Science, 40(1), 42532. doi: 10.4025/actascianimsci.v40 i1.42532

Farias, G. D., Cerdótes, L., Vaz, R. Z., Restle, J., Bitencourt, M. F., Alves, D. C., Fo., \&Brondani, I. L. (2018b). Biological efficiency of Charolais beef cows of different body sizes. Semina: Ciências Agrárias, 39(4), 17371748. doi: 10.5433/1679-0359.2018v39n $4 \mathrm{p} 1737$

Fonseca, M. A., Valadares, S. C., F., Henriques, L. T., Paulino, P. V. R., Detmann, E., Benedeti,
P. D. B., \& Amaral, P. M. (2012). Exigências nutricionais de vacas nelores primíparas lactantes. Revista Brasileira de Zootecnia, 41(5), 1222-1230. doi: 10.1590/S1516-35 982012000500020

Freetly, H. C., Kuehn, L. A., \& Cundiff, L. V. (2011). Growth curves of crossbred cows sired by Hereford, Angus, Belgian Blue, Brahman, Boran, and Tuli bulls, and the fraction of mature body weight and height at puberty. Journal Animal Science, 89(8), 2373-2379. doi: 10.2527/jas.2011-3847

Gabriel, L. R. A., Fo., Putti, F. F., Cremasco, C. P., Deyver, B., Chacur, M. G. M., \& Gabriel, L. R. A. (2016). Software to assess beef cattle body mass through the fuzzy body mass index. Engenharia Agrícola, 36(1), 179193. doi: 10.1590/1809-4430-Eng.Agric. v36n1p179-193/2016

Gano, G., Blanco, M., Casasús, I., Cortés-Lacruz, X., \& Villalba, D. (2016). Comparison of B-splines and non-linear functions to describe growth patterns and predict mature weight of female beef cattle. Animal Production Science, 56(11), 17871796. doi: 10.1071/AN15089

Gutiérrez, V., Espasadín, A. C., Machado, P., Bielli, A., Genovese, P., \& Carriquiry, M. (2014). Effects of calf early nutrition on muscle fiber characteristics and gene expression. Livestock Science, 167(1), 408-416. doi: 10.1016/j.livsci.2014.07.010

Leal, W. S., Costa, R. F., Cardoso, L. L., Mendonça, F. S., Cardoso, F. F., Yokoo, M. J., \& Weaber, R. L. (2018). Bio-economic model predicts economic values for beef production. Kansas Agricultural Experiment Station Research Reports, 4(1), 22-28. https://ainfo.cnptia.embrapa. br/digital/bitstream/item/190014/1/Bioeconomic-ModelPredicts-EconomicValues-for-Beef-Production.pdf 
Lemaster, C. T., Taylor, R. K., Ricks, R. E., \& Long, N. M. (2017). The effects of late gestation maternal nutrient restriction with or without protein supplementation on endocrine regulation of newborn and postnatal beef calves. Theriogenology, 87(1), 64-71. doi: 10.1016/j.theriogenology.2016.08.004

Lemes, J. S., Pimentel, M. A., Vaz, R. Z., Farias, L. B., \& Brauner, C. C. (2017). Performance efficiency of pasture-raised primiparous beef cows of three different biotypes and two milk production levels. Acta Scientiae Veterinariae, 45(1), e1461. Retrieved from http://www.redalyc.org/articulo.oa?id=28 9053641050

Marques, R. S., Cooke, R. F., Rodriguez, M. C., Moriel, P., \& Bohnert, D. W. (2016). Impacts of cow body condition score during gestation on weaning performance of the offspring. Livestock Science, 191(1), 174178. doi: 10.1016/j.livsci.2016.08.007

Michael, J. D., Baruselli, P. S., \& Campanile, G. (2019). Influence of nutrition, body condition, and metabolic status on reproduction in female beef cattle: a review. Theriogenology, 125(1), 277-284. doi: 10. 1016/j.theriogenology.2018.11.010

Moura, I. C. F., Kuss, F., Moletta, J. L., Menezes, L. F. G., Henrique, D. S., Cherubin, A. A., \& Paris, M. (2014). Productive and reproductive efficiency of Purunã beef cows of different categories. Semina: Ciências Agrárias, 35(4), 2555-2562. doi: 10.5433/1679-0359.2014v35n4Suplp 2555

National Research Council (2016). Nutrient requirements of beef cattle. Washington: National Academy Press.

Pacheco, R. F., Brondani, I. L., Alves, D. C., Fo., Cattelam, J., Mayer, A. R., Martini, A. P. M., \& Restle, J. (2020b). Reproductive performance of heifers of different weight classes in the first and second mating. Semina: Ciências Agrárias, 40(2), 819-830. doi: 10.5433/1679-0359.2019V40N2P819

Pacheco, R. F., Restle, J., Brondani, I. L., Alves, D. C., Fo., Cattelam, J., Mayer, A. R., \& Machado, D. S. (2020a). Calving probability in the first and second reproductive years of beef heifers that reached the recommended body weight at first breeding season. Revista Brasileira de Zootecnia, 49(1), e20190115. doi: 10.37 496/rbz4920190115

Restle, J., Pacheco, P. S., Padua, J. T., Moletta, J. L., Rocha, M. G. D., Silva, J. H. S. D., \& Freitas, A. K. D. (2005). Efeitos da taxa de ganho de peso pré-desmama de bezerras de corte e do nível nutricional pósparto, quando vacas, sobre a produção e composição do leite e o desempenho de bezerros. Revista Brasileira de Zootecnia, 34(1), 197-208. doi: 10.1590/S1516-3598 2005000100024

Rodrigues, P. F., Menezes, L. M., Azambuja, R. C. C., Suñér, W., Barbosa Silveira, I. D., \& Cardoso, F. F. (2014). Milk yield and composition from Angus and Anguscross beef cows raised in southern Brazil. Journal Animal Science, 92(6), 2668-2676. doi: 10.2527/jas.2013-7055

Scasta, J. D., Henderson, L., \& Smitht, T. (2015). Drought effect on weaning weight and efficiency relative to cow size in semiarid rangeland. Journal Animal Science, 93(12), 5829-5839. doi: 10.2527/jas.2015-9172

Silva, M. D., Lobato, J. F. P., Vaz, R. Z., Eloy, L. R., \& Vaz, M. B. (2018). Development and reproductive performance of Hereford heifers of different frame sizes up to mating at 14-15 months of age. Revista Brasileira de Zootecnia, 47(1), e20170031. doi: 10.1590/rbz472017003 
Silva, R. M., Souza, J. C., Fernandes, H. J., Abreu, U. G. P., Ferraz, P. B., Fo., \& Rosa, A. N. (2015). Eficiência produtiva ao desmame de vacas Nelore criadas no Pantanal. Arquivo Brasileiro de Medicina Veterinária e Zootecnia, 67(4), 1105-1110. doi: 10.1590/1678-4162-6909

Silveira, M. F., Restle, J., Brondani, I. L., Machado, D. S., Pacheco, R. F., Argenta., F. M., \& Hoffmann, F. (2019). Effect of age and genetic group on the development of calves weaned at 63 days until one year of age.Semina:CiênciasAgrárias, 40(4),16311638. doi: 10.5433/1679-0359.2019v40n $4 \mathrm{p} 1631$

Torres, H. A. L., Tineo, J. S. A., \& Raidan, F. S. S. (2015). Influência do escore de condição corporal na probabilidade de prenhez em bovinos de corte. Archivos de Zootecnia, 64(247), 255-259. doi: 10.21071/az.v64i 247.403

United States Department of Agriculture (2020). National Agricultural Statistics Service. Census of Agriculture. Retrieved from http://www.farmnews.com.br/mercado/ maiores-rebanhos-e-produtores-decarne-bovina/
Vara, C. C., Silveira, M. F., Vaz, R. Z., Restle, J., Machado, D. S., \& Macari, S. (2020). Body size in beef cows and its influence on calf production. Semina: Ciências Agrárias, 41(6), 3299-3310. doi: 10.5433/ 1679-0359.2020v41n6Supl2p3299

Vaz, R. Z., Lobato, J. F. P., \& Restle, J. (2010). Influence of weaning age on the reproductive efficiency of primiparous cows. Revista Brasileira de Zootecnia, 39(2), 299-307. doi: 10.1590/S1516-3598 2010000200011

Vaz, R. Z., Lobato, J. F. P., Restle, J., Costa, P. T., Ferreira, O. G. L., BethancourtGarcia, J. A., \& Costa, J. L. B. (2020a). Effect of live weight of beef cows on calf production efficiency. Research, Society and Development, 9(9), e679007632. doi: 10.33448/rsd-v9i9.7632

Vaz, R. Z., Silveira, M. F., Restle, J., Machado, D. S., Silva, H. R., Bethancourt-Garcia, J. A., \& Conceição, V. G. D. (2020b). Calving time and milk production in the bioeconomic efficiency of beef cattle herds. Research, Society and Development, 9(9), e216997240. doi: 10.33448/rsd-v9i9.7240 
